Government in the role of world peace-maker. The action already taken by the League of Nations, and approved by the Government, in promoting an inquiry into raw materials is obviously in line with the wishes of the signatories. The first essential step is to establish the facts in these matters beyond dispute, and the wisdom and urgency of this step are the more obvious in view of the refusal of certain countries to participate. If, in spite of such refusal, the British Government resolutely persists in a search for some way of reconciling the conflicting claims of different countries, convincing proof will be afforded of Great Britain's desire to promote peace based on a foundation secure because it is just.

\section{Belfast Meeting of the British Medical Association}

The British Medical Association held its one hundred and fifth annual meeting at Belfast last week under the presidency of Prof. R. J. Johnstone, professor of gynæcology in the Queen's University of Belfast. The main theme of his presidential address, entitled "Some Thoughts on Medical Education", was medical education, undergraduate and postgraduate. As a university teacher and member of the General Medical Council, Prof. Johnstone was able to speak with authority from practical experience. He said that the critic of medical education generally assumes that the teachers should, at the end of the five years curriculum, turn out the general practitioner as a finished product, and blames them if they do not do so, although no one expects a finished surgeon, anatomist or pathologist at the end of this period. The specialist must know almost everything about his subject, the general practitioner must know something about almost every medical subject, and the course the latter has to pursue cannot be less difficult than that needed by the former. Although clinical study must have a considerable place in the education of the under. graduate, it is a fallacy to consider that clinical training is the be-all and end-all of medical education. There must be an adequate background of human anatomy, physiology and pathology provided by medical education. Prof. Johnstone also alluded to the existence of dreary lectures and dull teachers, and suggested that courses of instruction in the art of lecturing might be instituted for those appointed to teaching posts.

\section{Nutritional Requirements of Pregnancy}

Aт a joint meeting of the Sections of Obstetrics and Gynæcology and Nutrition, a discussion took place on the nutritional requirements of pregnancy. Sir Robert McCarrison said that the food essentials needed by the prospective mother are, in order of precedence : (1) milk and milk products ; (2) whole or lightly milled cereals, particularly good wholemeal or standard bread, and oatmeal ; (3) green and leafy vegetables; (4) root vegetables, particularly potatoes, carrots and onions ; (5) fruit, including the tomato; (6) pulses ; (7) eggs ; (8) meat, including fish, fowl and glandular organs. To these should be added, in Great Britain, a daily teaspoonful dose of cod liver oil ; a portion of yeast extract is a wise precaution. Dame Louise McIlroy also stressed the value of fresh fruit and vegetables, herrings and wholemeal bread. She suggested that lessons and demonstrations in the preparation and storage of food might well form a part of the work of ante. natal clinics. Other speakers also emphasized the importance of an adequate supply of vitamins during pregnancy. The incidence of puerperal pyrexia seems to be diminished by these means.

\section{Maiden Castle, Dorchester: Excavations in 1937}

Excavatione have now been resumed at Maiden Castle, Dorchester, under the direction of Dr. R. E. Mortimer Wheeler and Colonel C. D. Drew on behalf of the Society of Antiquaries and the Dorset Natural History and Archæological Society (The Times, July 26). Three areas are to be explored in the coming season. At the eastern entrance, the unexpected discoveries made last autumn towards the close of last season's work will be further examined. These earlier fortifications, partly of masonry and dating from the third century B.c., which were found beneath the earthworks screening the entrance, include two outer gateways, which with the inner gateway constitute a complex plan hitherto unknown in prehistoric fortifications. Outside these are areas in which iron was smelted and burials took place. The latter should afford further evidence of the physical characters of the inhabitants, who according to the skeletons found last year were of a small build. Within the fort, investigations will be directed firstly to the Neolithic trenches found last year near the temple, which may have been part of the inner defensive system of the Neolithic partial occupation of c. 2000 B.C.; and secondly to the original western entrance, which was found in December last, but was not then explored. This last is marked by a gap in the rampart, which shows the original western limit of the castle, and should reveal the plan of the earliest gateway known. The first important discovery of the season is that of approach roads diverging in a north-easterly and south-easterly direction, which were superseded and abandoned in the first century B.c. and are thus among the earliest metalled roads known in Britain

\section{Evidence of Early Man at Bethlehem}

To the antiquities from Tell Duweir on view at the Wellcome Research Institution (see Nature, July 17, p. 99) have been added, since the opening of the exhibition, finds from the Bethlehem Bone Beds, which are being excavated by the Wellcome Marston Archæological Research Expedition to the Near East. The work of investigation is being carried out by Miss D. Bate and Miss E. Gardner. The great pit, from the clays of which these finds are derived, appears to be a swallow hole. Rock has been reached on two sides, while on the third side what appears to be only a thin sheet of sloping deposits remains; but until bottom has been reached the exact form cannot be determined. There are indications that the cavity may fork as deposits are followed further. Among the animal remains found in 1937, the most 